\title{
Tundrenone: An Atypical Secondary Metabolite from Bacteria with Highly Restricted Primary Metabolism
}

\section{Citation}

Puri, Aaron W., Emily Mevers, Timothy R. Ramadhar, Daniel Petras, Darren Liu, Jörn Piel, Pieter C. Dorrestein, E. Peter Greenberg, Mary E. Lidstrom, and Jon Clardy. 2018. "Tundrenone: An Atypical Secondary Metabolite from Bacteria with Highly Restricted Primary Metabolism." Journal of the American Chemical Society 140 (6): 2002-2006. doi:10.1021/jacs.7b12240. http:// dx.doi.org/10.1021/jacs.7b12240.

\section{Published Version}

doi:10.1021/jacs.7b12240

\section{Permanent link}

http://nrs.harvard.edu/urn-3:HUL.InstRepos:35014933

\section{Terms of Use}

This article was downloaded from Harvard University's DASH repository, and is made available under the terms and conditions applicable to Other Posted Material, as set forth at http:// nrs.harvard.edu/urn-3:HUL.InstRepos:dash.current.terms-of-use\#LAA

\section{Share Your Story}

The Harvard community has made this article openly available. Please share how this access benefits you. Submit a story. 


\section{Tundrenone: An Atypical Secondary Metabolite from Bacteria with Highly Restricted Primary Metabolism}

Aaron W. Puri, ${ }^{\dagger, \#}$ Emily Mevers, ${ }^{\ddagger, \#}$ Timothy R. Ramadhar, ${ }^{\ddagger, \# \odot ~ D a n i e l ~ P e t r a s, ~}{ }^{\S}{ }^{\circledR}$ Darren Liu, ${ }^{\dagger}$ Jörn Piel, ${ }^{\|}$

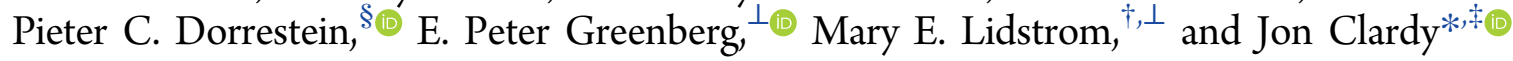

${ }^{\dagger}$ Department of Chemical Engineering, University of Washington, Seattle, Washington 98195, United States

${ }^{*}$ Department of Biological Chemistry and Molecular Pharmacology, Harvard Medical School, 240 Longwood Avenue, Boston, Massachusetts 02115, United States

${ }^{\S}$ Collaborative Mass Spectrometry Innovation Center, Skaggs School of Pharmacy and Pharmaceutical Sciences, University of California, San Diego, La Jolla, California 92093, United States

"Institute of Microbiology, Eidgenössische Technische Hochschule (ETH) Zürich, Vladimir-Prelog-Weg 4, 8093 Zürich, Switzerland

${ }^{\perp}$ Department of Microbiology, University of Washington, Seattle, Washington 98195, United States

Supporting Information

ABSTRACT: Methane-oxidizing bacteria, aerobes that utilize methane as their sole carbon and energy source, are being increasingly studied for their environmentally significant ability to remove methane from the atmosphere. Their genomes indicate that they also have a robust and unusual secondary metabolism. Bioinformatic analysis of the Methylobacter tundripaludum genome identified biosynthetic gene clusters for several intriguing metabolites, and this report discloses the structural and genetic characterization of tundrenone, one of these metabolites. Tundrenone is a highly oxidized metabolite that incorporates both a modified bicyclic chorismate-derived fragment and a modified lipid tail bearing a $\beta, \gamma$-unsaturated $\alpha$-hydroxy ketone. Tundrenone has been genetically linked to its biosynthetic gene cluster, and quorum sensing activates its production. M. tundripaludum's genome and tundrenone's discovery support the idea that additional studies of methane-oxidizing bacteria will reveal new naturally occurring molecular scaffolds and the biosynthetic pathways that produce them.

$\mathrm{R}$ esearch on natural products, genetically encoded members of a small-molecule miscellany, has repeatedly shown that investigating new patches of organismal space can reveal new chemotypes along with their associated biosynthetic machinery and regulatory elements. The increasing availability of genomic sequences has enabled the discovery of previously unreported molecular diversity through bioinformatic analyses-an approach usually called "gene-to-molecule". In a variation on this approach, we recently characterized a quorum sensing system ${ }^{1}$ in the aerobic methane-oxidizing bacterium Methylobacter tundripaludum $21 / 22^{2}$ that activates the expression of a colocated biosynthetic gene cluster (BGC) detected by the antiSMASH genome mining tool. ${ }^{3}$ The same quorum sensing system regulated the production of a UV-active molecule observed in the $M$. tundripaludum supernatant, which was the likely product of the BGC. ${ }^{1}$ Since quorum sensing systems in bacteria regulate gene expression on the basis of cell density and often control the production of molecules such as siderophores, antibiotics, and electron shuttles, we decided to further investigate the molecule, which we named tundrenone (1) (Figure 1a). ${ }^{4-7}$

a)<smiles>C=C(OCC(=C)C(O)C(=O)C[Te]CCC)C(=O)O[C@H]1C2CC(=O)C(O)=C2C=C[C@H]1O</smiles>

Tundrenone (1)

b)

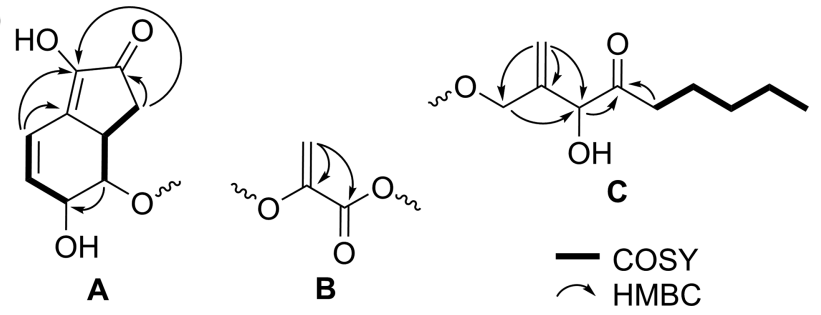

Figure 1. (a) Structure of tundrenone (1). (b) Partial structures assembled by $2 \mathrm{D}$ NMR data.

We isolated approximately $3 \mathrm{mg}$ of $\mathbf{1}$ from the ethyl acetate extract of $12 \mathrm{~L}$ of supernatant with subsequent $\mathrm{C} 18$ solid-phase extraction and UV-absorbance-guided semi-preparative HPLC. The molecular formula of $1\left(\mathrm{C}_{22} \mathrm{H}_{28} \mathrm{O}_{8}\right)$, obtained by HRMS (observed $[\mathrm{M}+\mathrm{H}]^{+} m / z$ 421.1857, theoretical $[\mathrm{M}+\mathrm{H}]^{+} \mathrm{m} / z$ 421.1857, $0 \mathrm{ppm}$ ), indicated a highly oxygenated metabolite with no matches in spectral databases. ${ }^{8}$ The ${ }^{13} \mathrm{C}$ NMR spectrum revealed numerous shielded carbon atoms, including three carbonyls - two ketones (200.9 and 209.9 ppm) and one ester (161.5 ppm) - and eight olefinic carbons between 96.9 and $149.3 \mathrm{ppm}$ that accounted for seven of the nine degrees of

Received: November 20, 2017

Published: January 23, 2018 
unsaturation. There were also four oxygenated $\mathrm{sp}^{3}$-hybridized carbons with resonances between 62.1 and $77.8 \mathrm{ppm}$.

Further analysis with an array of $2 \mathrm{D}$ NMR experiments (gHSQC, gHMBC, gCOSY, and ROESY) led to three partial structures A-C (Figure $1 \mathrm{~b}$ ) that contained all of the carbon atoms in 1. Partial structure A consists of one ketone, two olefins, and two oxygenated $\mathrm{sp}^{3}$-hybridized carbons, all within a [4.3.0] bicyclic system. Partial structure $\mathbf{B}$ consists of a dehydroserine hydroxy acid with exo-methylene signals at $\delta_{\mathrm{C}}$ 149.3 and 96.9 and $\delta_{\mathrm{H}} 5.29$ and 5.03. The last partial structure, C, contains four spin systems and was deduced to be a modified lipid tail functionalized with only an exo-methylene group, an alcohol, and a ketone. Partial structure $\mathbf{C}$ is structurally similar to ketalin, a metabolite previously isolated from Streptomyces sp. strain 1668. ${ }^{9}$ Partial structures A-C were connected to form the planar structure of $\mathbf{1}$ using key HMBC correlations. A and B were connected by the observation of an HMBC correlation between $\mathrm{H} 9$ and $\mathrm{C} 10$ to form a vinylic ether linkage. The connection between $\mathbf{B}$ and $\mathbf{C}$ was established by an HMBC correlation between $\mathrm{H} 12$ and $\mathrm{C} 11$, thus forming an ester linkage and completing the planar structure elucidation of $\mathbf{1}$.

The three contiguous stereocenters in the tetrahydroindenone core of 1 were assigned using NMR and chiroptical data and theoretical calculations. The relative configuration was determined by comparing experimental NMR data for $\mathbf{1}$ with roughly calculated ${ }^{3} J_{\mathrm{HH}}$ coupling constants (Figure 2) and
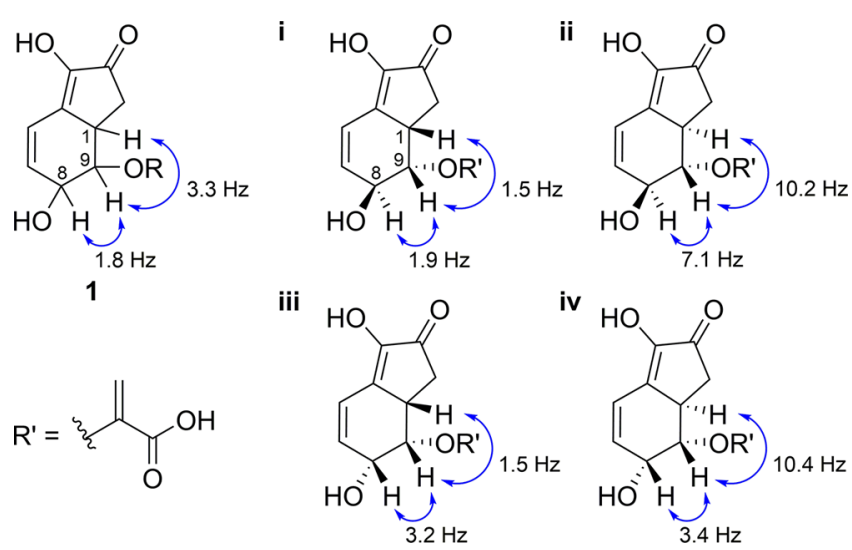

Figure 2. Analysis of ${ }^{3} J_{\mathrm{HH}}$ values [measured vs calculated (i-iv)].

DFT-calculated ${ }^{13} \mathrm{C}$ chemical shifts for i, ii, iii, and iv, where the ester on the acyclic motif was simplified to a carboxylic acid (Table 1). ${ }^{10}$ The measured ${ }^{3} J_{\mathrm{HH}}$ for $\mathrm{H} 1 / \mathrm{H} 9$ in $d_{6}$-DMSO was $3.3 \mathrm{~Hz}$, which is indicative of a cis $\mathrm{H1} / \mathrm{H} 9$ configuration and is in good agreement with the calculated ${ }^{11}{ }^{3} J_{\mathrm{HH}}$ for cis- $\mathrm{H} 1 / \mathrm{H} 9$ configured $\mathbf{i}$ and iii $(1.5 \mathrm{~Hz})$ versus trans-H1/H9-configured ii and iv $(10.2-10.4 \mathrm{~Hz})$. However, the calculated ${ }^{3} J_{\mathrm{HH}}$ for transand cis-configured H8/H9 in i and iii, respectively, could not be used to confidently resolve their relative configuration. To determine whether the relative stereochemistry of the three contiguous stereocenters in $\mathbf{1}$ mimics $\mathbf{i}$ or iii, the measured ${ }^{13} \mathrm{C}$ chemical shifts for $\mathbf{1}$ were compared with the DFT-calculated Boltzmann-weighted shifts for $\mathbf{i}$ and iii. The latter were obtained through a highly accurate method developed by Tantillo ${ }^{12}$ that we had previously used. ${ }^{13}$ Excellent agreement between measured and calculated ${ }^{13} \mathrm{C}$ chemical shifts of $\mathbf{1}$ and $\mathbf{i}$ was observed, with a corrected mean absolute deviation (CMAD) of $1.6 \mathrm{ppm}$, whereas the CMAD for iii was 5.3
Table 1. Comparison of Experimental (1) and Calculated (i, iii) ${ }^{13} \mathrm{C}$ NMR Chemical Shifts

\begin{tabular}{clll} 
& \multicolumn{3}{c}{${ }^{13}$ C NMR chemical shifts $(\mathrm{ppm})$} \\
\cline { 2 - 4 } atom $^{a}$ & exptl $(\mathbf{1})^{b}$ & calcd (i) $)^{c, d}$ & calcd (iii) ${ }^{c, d}$ \\
C1 & 31.0 & 35.2 & 40.2 \\
C2 & 33.7 & 34.8 & 36.4 \\
C3 & 200.9 & 199.9 & 199.0 \\
C4 & 147.5 & $\mathbf{1 4 4 . 8}$ & 143.7 \\
C5 & 134.6 & 134.5 & 136.5 \\
C6 & 121.7 & 123.6 & 121.1 \\
C7 & 130.0 & 132.6 & 140.5 \\
C8 & 62.1 & $\mathbf{6 2 . 6}$ & 71.3 \\
C9 & 76.2 & 73.1 & 83.3 \\
C10 & 149.3 & $\mathbf{1 4 8 . 6}$ & 153.2 \\
C11 & 161.5 & $\mathbf{1 6 2 . 0}$ & 163.7 \\
C22 & 96.9 & 97.1 & 107.1 \\
\hline & CMAD & 1.6 & 5.3 \\
& largest $\Delta \delta$ & $4.2(\mathrm{C} 1)$ & $10.5(\mathrm{C} 7)$
\end{tabular}

${ }^{a}$ See Figure 1 for labeling. ${ }^{b}$ Data in $d_{6}$-DMSO. ${ }^{c}$ Calculated at the SCRF-(IEFPCM/DMSO)-mPW1PW91/6-311+G(2d,p)//B3LYP/6$31+\mathrm{G}(\mathrm{d}, \mathrm{p})$ level of theory, scaled, and Boltzmann weighted. ${ }^{d}$ The calculated chemical shift closest in magnitude to the experimental chemical shift for each atom is bolded. ${ }^{e} \mathrm{CMAD}$ is the average value of $\left|\delta_{\text {calcd }}-\delta_{\text {exptl }}\right|$

ppm (Table 1). Thus, the chemical shift data strongly support a trans-configured $\mathrm{H} 8 / \mathrm{H} 9$ and a cis-configured $\mathrm{H} 1 / \mathrm{H} 9$.

The absolute stereochemistry of the tetrahydroindenone core was assigned by comparing the specific rotation $\left([\alpha]_{\mathrm{D}}\right)$ for $\mathbf{1}$ with the DFT-calculated Boltzmann-weighted optical rotation for $\mathbf{i}$, where the three stereogenic centers bear the $S, S, S$ configuration. Tundrenone (1) exhibited a specific rotation of -66.4 , which has the opposite sign to the calculated $[\alpha]_{\mathrm{D}}$ of $\mathbf{i}$ $(+197) .{ }^{14}$ Thus, the measured and calculated chiroptical data strongly suggest that the absolute configuration of the three contiguous stereocenters in $\mathbf{1}$ is $R, R, R$. Unfortunately, all attempts to determine the configuration of the stereogenic center bearing the hydroxyl group in the fatty acid moiety failed. Attempts to convert the hydroxyl group to a Mosher ester via traditional methods or Mitsunobu conditions yielded no desired product by HRMS.

With the structure of 1 secure, we investigated the connections between $\mathbf{1}$ and the BGC co-regulated by quorum sensing in $M$. tundripaludum. While genetic manipulation of this strain is difficult, an in-frame null mutation was made in an annotated acyl-CoA ligase gene (tunJ, T451DRAFT 0812) in the cluster, subsequently named the tun cluster. This mutant did not produce $\mathbf{1}$ (Figure 3). Additionally, 1 was not detected in the supernatant of the acyl-homoserine lactone synthase mutant $\Delta m b a I$ but returned when this strain was grown with the addition of the quorum sensing signal $3-\mathrm{OH}-\mathrm{C}_{10}-\mathrm{HSL}$. These experiments confirmed that $\mathbf{1}$ is produced in a quorumsensing-dependent manner by the tun cluster, ${ }^{1}$ with $2.7 \pm 0.7$ $\mu \mathrm{M}$ detected in the supernatant of stationary-phase wild-type $M$. tundripaludum cultures. The $\Delta$ tunJ mutant still produces the $3-\mathrm{OH}-\mathrm{C}_{10}$-HSL signal (Figure S9), so loss of $\mathbf{1}$ in this strain is not due to disruption of the quorum sensing system.

A plausible biosynthesis of $\mathbf{1}$ that largely reconciles most of the genes in the tun cluster was formulated (Figure 4). The bicyclic western fragment in 1 clearly resembles chorismate (2). Subsequent evaluation of the tun cluster revealed that TunN and TunO resemble-both in sequence and putative 


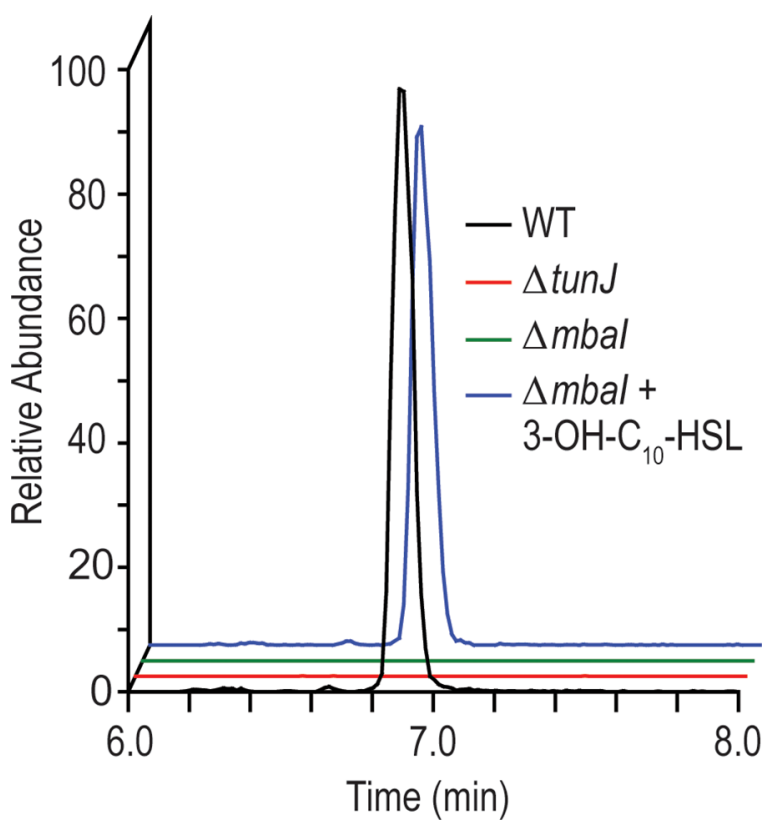

Figure 3. Extracted ion chromatogram $(m / z$ 421.18-421.20) of 1 from supernatant extracts of $M$. tundripaludum strains, including the wild type (WT), the acyl-CoA ligase mutant $(\Delta t u n J)$, and the acylhomoserine lactone synthase mutant $(\Delta \mathrm{mbaI})$ in the absence and presence of $1 \mu \mathrm{M} 3-\mathrm{OH}-\mathrm{C}_{10}-\mathrm{HSL}$.

function-components of 2-amino-2-deoxyisochorismate synthase (ADS), which utilizes 2 and an ammonia nucleophile, and isochorismate synthase (ICS), which uses 2 and a water nucleophile. ${ }^{15}$ It is important to note that TunN and TunO are also homologous to anthranilate synthase, which is not found elsewhere in the genome. Therefore, these enzymes may also be necessary for the synthesis of aromatic amino acids in $M$. tundripaludum, as these bacteria are prototrophic for all amino acids. In this regard, it is important to note that $\operatorname{tunN}$ and tunO are constitutively expressed, ${ }^{1}$ which is consistent with an essential role. In support of this, multiple attempts to knock out either tunN or tunO were unsuccessful. On the basis of the propensity of TunN and TunO to utilize 2 as a coupling partner, a possible route to the tetrahydroindenone core in $\mathbf{1}$ may initially involve a TunNO-catalyzed $\mathrm{S}_{\mathrm{N}} 2^{\prime}$ (or $\mathrm{S}_{\mathrm{N}} 1^{\prime}$ ) transformation with 2 and phosphoenolpyruvate (3), or a related nucleophile, to generate tricarboxylate cyclohexadiene adduct 4 . Following adduct formation, cyclization of $\mathbf{4}$ to give tetrahydroindenone intermediate $\mathbf{5}$ could occur via catalysis involving the redox enzymes TunDEM and the glutathione $S$ transferase-like enzyme TunP. Alternatively, cyclization of 4 may be facilitated by a thiamine pyrophosphate-dependent enzyme encoded elsewhere in the genome through a hypothetical formal $\alpha$-keto acid decarboxylation/5-exo-trig ring closure/1,6-conjugate hydroxyl addition sequence. Activation of 5 for coupling with the eastern fragment (13) (vide infra) may involve TunJ-activated TunH-thioester adduct 6 formed via TunHJ. The supernatant of the $\Delta$ tunJ mutant strain contains both 5 and 13, thus supporting this hypothesis (Figures S10 and S11).

The biogenesis of the acyclic eastern fragment of $\mathbf{1}$ plausibly begins through formation of 9 via condensation of dihydroxyacetone phosphate (7) with $\beta$-keto thioester 8 by TunC, which is similar to AfsA and related enzymes that link 7 and an activated $\beta$-keto acid en route to bacterial butyrolactone signals, such as A factor. ${ }^{16}$ An intramolecular aldol-like cyclization of 9 catalyzed by the $\delta$-aminolevulinic acid dehydratase homologue TunB generates lactone 10. The tun cluster contains a gene encoding TunK, a homologue of the quorum-quenching enzyme AidH, a lactonase that hydrolyzes acyl-homoserine $\gamma$ lactones. ${ }^{17}$ Thus, it is possible that TunK hydrolyzes the lactone in 10 to form $\beta$-keto acid 11. Subsequent decarboxylation and $\beta$-hydroxyl elimination on $\mathbf{1 1}$ followed by $\mathrm{S}_{\mathrm{N}} 2^{\prime}$ displacement of the phosphate group with water on 12, possibly catalyzed by haloacid dehydratase homologue TunA, would afford $\beta, \gamma$ unsaturated ketone 13. The final step involves coupling of 13 with TunJ-activated and ACP-bound 6, presumably through the action of condensation enzyme TunI, to generate 1. Further empirical investigation will be needed to elaborate the postulated biosynthesis of the western and eastern fragments.

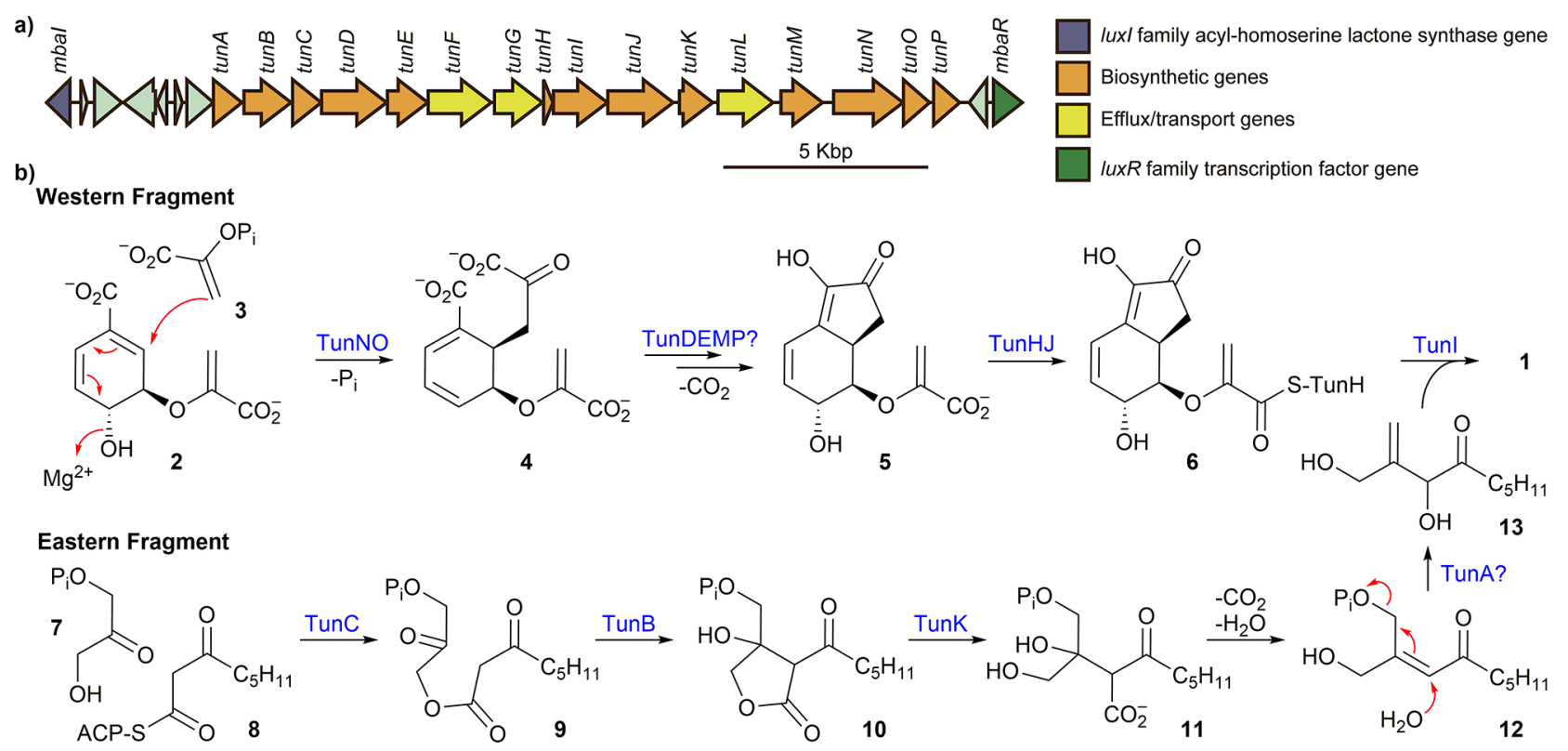

Figure 4. (a) Annotated tun biosynthetic gene cluster. (b) Proposed biogenesis of $\mathbf{1}$. 
This initial foray into a gene-to-molecule study on a methane-oxidizing bacterium that relies on methane as the sole carbon and energy source turned up both significant results and promising avenues for future research. In the gene-tomolecule realm, it led to a highly unusual molecule and associated biosynthetic puzzles. Tundrenone (1) incorporates a highly modified chorismate moiety that has not been observed previously. Chorismate serves as the starting material for metabolites ranging from the aromatic amino acids (phenylalanine, tyrosine, and tryptophan) to the plant hormone salicylic acid, large numbers of plant alkaloids, and many metabolites. However, none feature the bicyclic modification seen in $\mathbf{1}$. The formation is putatively attributed to the action of TunNO, an enzyme incorporating features of known enzymes along chorismate-containing biosynthetic pathways but with a carbon-centered nucleophile. In addition to these structural and mechanistic surprises, the quorum-sensing-regulated production of 1 suggests an as yet unknown functional role. ${ }^{4,18}$ This project has created both molecular and genetic tools that will be essential in defining the unknown function(s). Finally, further mechanistic understanding will allow the possibility to create a synthetic biology platform leading to microbial factories that utilize methane, the major component of natural gas, as a feedstock for the synthesis of high-value small molecules. ${ }^{19}$

\section{ASSOCIATED CONTENT}

\section{S Supporting Information}

The Supporting Information is available free of charge on the ACS Publications website at DOI: 10.1021/jacs.7b12240.

Experimental and computational procedures, NMR spectra, CD spectrum, chromatograms, Cartesian coordinates, and additional computational data (PDF)

\section{AUTHOR INFORMATION}

\section{Corresponding Author}

*jon_clardy@hms.harvard.edu

\section{ORCID}

Timothy R. Ramadhar: 0000-0002-7063-5445

Daniel Petras: 0000-0002-6561-3022

Pieter C. Dorrestein: 0000-0002-3003-1030

E. Peter Greenberg: 0000-0001-9474-8041

Jon Clardy: 0000-0003-0213-8356

\section{Author Contributions}

\#A.W.P., E.M., and T.R.R. contributed equally to this work.

\section{Notes}

The authors declare no competing financial interest.

To facilitate future compound dereplication, MS/MS spectra were annotated and included in the Global Natural Product Social Molecular Networking database (GNPS) ${ }^{8}$ under MassIVE ID MSV000081637 (https://massive.ucsd.edu/).

\section{ACKNOWLEDGMENTS}

This work was supported by the U.S. Department of Energy, Office of Science, Office of Biological and Environmental Research (Award DE-SC-0010556 to M.E.L.) and the U.S. National Institutes of Health (K99 GM118762 to A.W.P., P41 GM103484 and S10 RR029121 to P.C.D., R01 GM059026 to E.P.G., and R01 AT009874 to J.C.). D.P. was supported by the Deutsche Forschungsgemeinschaft (DFG) (Grant PE 2600/1). Quantum-chemical calculations were run on the Odyssey cluster supported by the FAS Division of Science, Research
Computing Group at Harvard University. We thank Amy Schaefer at the University of Washington for helpful discussions and Marina Kalyuzhnaya at San Diego State University for providing resources for strain growth in San Diego.

\section{REFERENCES}

(1) Puri, A. W.; Schaefer, A. L.; Fu, Y.; Beck, D. A.; Greenberg, E. P.; Lidstrom, M. E. J. Bacteriol. 2017, 199, e00773-16.

(2) Kalyuzhnaya, M. G.; Lamb, A. E.; McTaggart, T. L.; Oshkin, I. Y.; Shapiro, N.; Woyke, T.; Chistoserdova, L. Genome Announc. 2015, 3, e00103-15.

(3) Blin, K.; Wolf, T.; Chevrette, M. G.; Lu, X.; Schwalen, C. J.; Kautsar, S. A.; Suarez Duran, H. G.; de Los Santos, E. L. C.; Kim, H. U.; Nave, M.; Dickschat, J. S.; Mitchell, D. A.; Shelest, E.; Breitling, R.; Takano, E.; Lee, S. Y.; Weber, T.; Medema, M. H. Nucleic Acids Res. 2017, 45, W36.

(4) Bandara, H. M. H. N.; Lam, O. L. T.; Jin, L. J.; Samaranayake, L. Crit. Rev. Microbiol. 2012, 38, 217.

(5) Duerkop, B. A.; Varga, J.; Chandler, J. R.; Peterson, S. B.; Herman, J. P.; Churchill, M. E. A.; Parsek, M. R.; Nierman, W. C.; Greenberg, E. P. J. Bacteriol. 2009, 191, 3909.

(6) Pierson, L. S., III; Keppenne, V. D.; Wood, D. W. J. Bacteriol. 1994, 176, 3966.

(7) Seyedsayamdost, M. R.; Chandler, J. R.; Blodgett, J. A. V.; Lima, P. S.; Duerkop, B. A.; Oinuma, K.-I.; Greenberg, E. P.; Clardy, J. Org. Lett. 2010, 12, 716.

(8) Wang, M.; Carver, J. J.; Phelan, V. V.; Sanchez, L. M.; Garg, N.; Peng, Y.; Nguyen, D. D.; Watrous, J.; Kapono, C. A.; Luzzatto-Knaan, T.; Porto, C.; Bouslimani, A.; Melnik, A. V.; Meehan, M. J.; Liu, W.-T.; Crüsemann; Boudreau, P. D.; Esquenazi, E.; Sandoval-Calderón; Kersten, R. D.; Pace, L. A.; Quinn, R. A.; Duncan, K. R.; Hsu, C.-C.; Floros, D. J.; Gavilan, R. G.; Kleigrewe, K.; Northen, T.; Dutton, R. J.; Parrot, D.; Carlson, E. E.; Aigle, B.; Michelsen, C. F.; Jelsbak, L.; Sohlenkamp, C.; Pevzner, P.; Edlund, A.; McLean, J.; Piel, J.; Murphy, B. T.; Gerwick, L.; Liaw, C.-C.; Yang, Y.-L.; Humpf, H.-U.; Maansson, M.; Keyzers, R. A.; Sims, A. C.; Johnson, A. R.; Sidebottom, A. M.; Sedio, B. E.; Klitgaard, A.; Larson, C. B.; Boya P, C. A.; TorresMendoza, D.; Gonzalez, D. J.; Silva, D. B.; Marques, L. M.; Demarque, D. P.; Pociute, E.; O’Neill, E. C.; Briand, E.; Helfrich, E. J. N.; Granatosky, E. A.; Glukhov, E.; Ryffel, F.; Houson, H.; Mohimani, H.; Kharbush, J. J.; Zeng, Y.; Vorholt, J. A.; Kurita, K. L.; Charusanti, P.; McPhail, K. L.; Nielsen, K. F.; Vuong, L.; Elfeki, M.; Traxler, M. F.; Engene, N.; Koyama, N.; Vining, O. B.; Baric, R.; Silva, R. R.; Mascuch, S. J.; Tomasi, S.; Jenkins, S.; Macherla, V.; Hoffman, T.; Agarwal, V.; Williams, P. G.; Dai, J.; Neupane, R.; Gurr, J.; Rodriguez, A. M. C.; Lamsa, A.; Zhang, C.; Dorrestein, K.; Duggan, B. M.; Almaliti, J.; Allard, P.-M.; Phapale, P.; Nothias, L.-F.; Alexandrov, T.; Litaudon, M.; Wolfender, J.-L.; Kyle, J. E.; Metz, T. O.; Peryea, T.; Nguyen, D.-T.; VanLeer, D.; Shinn, P.; Jadhav, A.; Müller, R.; Waters, K. M.; Shi, W.; Liu, X.; Zhang, L.; Knight, R.; Jensen, P. R.; Palsson, B. Ø.; Pogliano, K.; Linington, R. G.; Gutiérrez, M.; Lopes, N. P.; Gerwick, W. H.; Moore, B. S.; Dorrestein, P. C.; Bandeira, N. Nat. Biotechnol. 2016, 34, 828.

(9) König, W. A.; Drautz, H.; Zähner, H. Liebigs Ann. Chem. 1980, $1980,1384$.

(10) These truncated diastereomers were modeled in order to mitigate complexity and computational burden arising from the flexible alkyl chain in 1 . We do not expect the absence of the pendant chain to exhibit a significant impact on the ability to compare experimental and calculated data.

(11) Haasnoot, C. A. G.; de Leeuw, F. A. A. M.; Altona, C. Tetrahedron 1980, 36, 2783.

(12) (a) Lodewyk, M. W.; Soldi, C.; Jones, P. B.; Olmstead, M. M.; Rita, J.; Shaw, J. T.; Tantillo, D. J. J. Am. Chem. Soc. 2012, 134, 18550. (b) Lodewyk, M. W.; Siebert, M. R.; Tantillo, D. J. Chem. Rev. 2012, 112, 1839. (c) Scaling factors: Pierens, G. K. J. Comput. Chem. 2014, $35,1388$. 
(13) Kim, K. H.; Ramadhar, T. R.; Beemelmanns, C.; Cao, S.; Poulsen, M.; Currie, C. R; Clardy, J. Chem. Sci. 2014, 5, 4333.

(14) The difference in magnitude between the experimental and calculated $[\alpha]_{\mathrm{D}}$ is likely attributed to the dilute nature of the experimental sample and the truncation of the tail in $\mathbf{i}$.

(15) He, Z.; Stigers Lavoie, K. D.; Bartlett, P. A.; Toney, M. D. J. Am. Chem. Soc. 2004, 126, 2378.

(16) (a) Ando, N.; Matsumori, N.; Sakuda, S.; Beppu, T.; Horinouchi, S. J. Antibiot. 1997, 50, 847. (b) Kato, J. Y.; Funa, N.; Watanabe, H.; Ohnishi, Y.; Horinouchi, S. Proc. Natl. Acad. Sci. U. S. A. 2007, 104, 2378.

(17) Mei, G.-Y.; Yan, X.-X.; Turak, A.; Luo, Z.-Q.; Zhang, L.-Q. Appl. Environ. Microbiol. 2010, 76, 4933.

(18) Schuster, M.; Sexton, D. J.; Diggle, S. O.; Greenberg, E. P. Annu. Rev. Microbiol. 2013, 67, 43.

(19) Kalyuzhnaya, M. G.; Puri, A. W.; Lidstrom, M. E. Metab. Eng. 2015, 29, 142. 